\title{
UPAYA PENCEGAHAN COVID-19 DALAM PERSPEKTIF ISLAM
}

DOI: https: //doi.org/10.33024/jkpm.v4i5.3058

\author{
Saipul Al Sukri ${ }^{*}$, Ahmad Fauzi², Afrinaldy rustam³ ${ }^{3}$ Achmad Ghozali \\ Rusdi $^{4}$, Zulfahmi ${ }^{5}$ \\ 1-5Universitas Islam negeri Sultan syarif Kasim \\ Disubmit: 01 Februari 2021 Diterima: 05 Maret $2021 \quad$ Diterbitkan: 30 September 2021
}

Email Korespondensi: saipul.alsukri@gmail.com

\begin{abstract}
ABSTRAK
Pola hidup bersih dan menjaga protokol kesehatan $3 \mathrm{M}$ harus tetap berjalan meskipun pelaksanaan vaksinasi sudah dilakukan. Langkah ini bertujuan agar kasus baru dan penyebaran Covid19 bisa di hentikan. Dalam upaya itu, dosen dilingkungan UIN Sultan Syarif Kasim Riau melaksanakan Kegiatan pengabdian kepada masyarakat yang dimaksudkan memberikan perspektif lain dalam usaha pencegahan dari penularan virus. Salah satunya adalah dengan menjaga kebersihan diri. Kegiatan pengabdian dilaksanakan di desa Tlk.Latak Kab. Bengkalis. kegiatan ini dilaksanakan di aula kantor desa dan diikuti oleh perangkat desa, tokoh masyarakat dan warga. Di akhir sesi, tim pengabdi memberikan cindera mata serta alat prokes berupa masker dan hand sanitizer pada perangkat desa.
\end{abstract}

Kata Kunci: Kebersihan dalam Islam, penyuluhan kesehatan, Covid-19

\begin{abstract}
A clean lifestyle and maintaining $3 \mathrm{M}$ health protocols must continue even though the vaccination has been carried out. This step is intended to stop new cases and the spread of Covid-19. In that effort, lecturers within the UIN Sultan Syarif Kasim Riau carried out community service activities which were intended to provide another perspective in efforts to prevent virus transmission. One of them is to maintain personal hygiene. Service activities are carried out in the village of Tlk. Latak Kab. Bengkalis. This activity was carried out in the village office hall and was attended by village officials, community leaders and residents. At the end of the session, the service team provided souvenirs and health care tools in the form of masks and hand sanitizers to village officials.
\end{abstract}

Keywords: Cleanliness in Islam, health education, Covid-19 


\section{PENDAHULUAN}

Kebersihan merupakan bagian dari usaha manusia untuk senantiasa menjaga diri dan lingkungan dari hal yang kotor dan buruk. Kebersihan dan kesehatan merupakan hal yang berbanding lurus. Jika seseorang peduli dan sadar akan kebersihan maka kesehatannya akan terjaga dengan baik pula. Sebaliknya jika kebersihan membawa kita pada hal yang sehat dan bersih maka kotor akan menghadirkan penyakit dan pada akhirnya akan berakibat pada kerusakan dan penderitaan. Nabi Muhammad SAW, bersabda yang artinya: Kebersihan merupakan sebagian dari iman (HR Muslim).

Kita juga diingatkan untuk memakan makanan yang Halal dan baik sebagaimana yang dijelaskan dalam firman Allah yang artinya: "Hai sekalian manusia, makanlah yang halal lagi baik dari apa yang terdapat di bumi, dan janganlah kamu mengikuti langkah-langkah setan; karena sesungguhnya setan itu adalah musuh yang nyata bagimu" (Al-Baqarah: 168). Makanan Dalam islam selain sebagai sumber tenaga juga memberikan porsi yang besar untuk kesehatan dan kecerdasan seseorang (Rifa'i, Irwansyah, Sholihah, \& Yuliawati, 2020). Sebagaimana disampaikan oleh Al-Asy'ats seorang ilmuwan muslim $(390 \mathrm{H})$ dalam bukunya yang berjudul Al-Hidza'wal Muhthady, bahwa makanan yang dikonsumsi ada yang berfungsi membesarkan tubuh jasmani dan ada yang menambahkan kecerdasan (Waharjani, 2015). oleh karenanya, manakan yang dimakanan harus diperhatikan betul zat, cara menyembelih sampai kepada cara mengolahnya.

Akhir 2019 tepatnya pada bulan desember, penduduk dunia dikejutkan dengan suatu wabah virus yang melanda Wuhan Provinsi Hubei China (Lu, Stratton, \& Tang, 2020), (I.I. et al., 2020). Virus ini diberitakan berkembang dari pasar makanan laut di Huanan. Pasar ini terkenal menjual beragam satwa liar seperti katak, ular, kelelawar dan tikus untuk konsumsi karena dipercaya hewan tersebut dapat memiliki manfaat untuk kesehatan (Fehr, Anthony R and Perlman \& Stanley, 2015) dan obat tradisional (Plotkin,2020). Virus ini memiliki sebaran yang cukup cepat, dan berkembang di seluruh dunia. Pada tanggal tanggal 11 Maret 2020 WHO kemudian menetapkan covid-19 sebagai pandemik global (Zheng, Ma, Zhang, \& Xie, 2020).

Di Indonesia, kasus pertama kali terkonfirmasi pada awal maret 2020 (Yuliana, 2020). Perkembangan virus ini tergolong sangat cepat, hal ini karena perantara/inang tempat bersarangnya virus ini kendaraannya sangat mobile dan hiperaktif (manusia). Berbeda dengan virus sars dan mers dimana penularan virus terjadi lewat inang binatang. Berbagai langkah dilakukan pemerintah guna membatasi pergerakan manusia ini. Misalnya dengan menjaga jarak fisik (physical distancing), bekerja dari rumah, belajar dirumah dan beribadah di rumah.

Penanganan penularan wabah sesuai ajaran islam dalam hal ini sangat relevan untuk dipelajari, mengingat banyak literasi sejarah yang memberitakan kepada kita tentang wabah yang berkembang pada masa islam dahulu. Berdasarkan penjelasan diatas, melihat peningkatan kasus covid-19 yang belum menunjukkan grafik yang landai maka diperlukan suatu cara pencegahan alternatif dalam sudut pandang islam. Dalam upaya tersebut, tim pengabdi dari Dosen lingkungan UIN Suska Riau melakukan pengabdian kepada masyarakat dengan tema "kebersihan menurut ajaran islam dalam upaya pencegahan covid$19 "$. 


\section{MASALAH}

Pemilihan Desa Tlk. Latak Kabupaten Bengkalis sebagai lokasi pengabdian mengingat tempat ini sangat jauh dari pusat kota. Jarang bahkan belum ada kegiatan penyuluhan kesehatan yang dilakukan baik itu dari pemerintah daerah apalagi dari perguruan tinggi. Pemilihan aparatur desa sebagai mitra mengingat keseharian aparat desa yang banyak bersentuhan langsung dengan masyarakat. $\mathrm{Hal}$ itu bisa berupa pengurusan surat menyurat maupun urusan lain. Kerumunan yang terjadi ini sangat memungkinkan menjadinya tempat penularan virus.

Sebelum melakukan pengabdian, tim melakukan kunjungan ke mitra pengabdi dan melihat sendiri bagaimana protokol kesehatan tidak dilakukan. Pengabaian jaga jarak minimal 1 meter, tidak menggunakan masker dan belum tersedianya sarana cuci tangan yang memadai menjadi persoalan saat itu. Dengan adanya pengabdian ini, akan ada penambahan pengetahuan bagi mitra. Sehingga juga mendorong mitra untuk dapat memberikan himbauan ke warga sekitar.

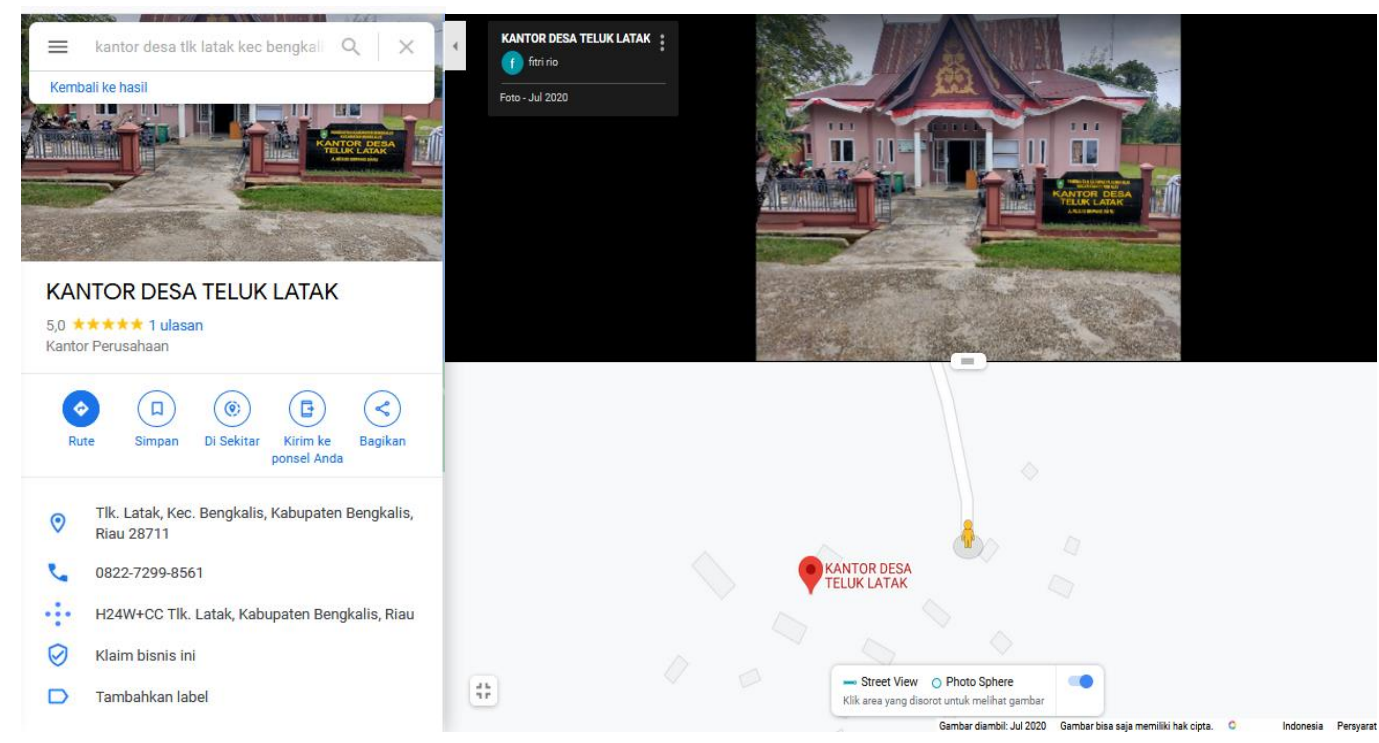

Gambar 1. Peta lokasi kegiatan pengabdian

\section{METODE}

Kegiatan pengabdian ini diadakan di aula kantor Desa Tlk. Latak yang berlokasi di Kec. Bengkalis, Kab. Bengkalis Prov. Riau. Beberapa tahapan dalam pelaksanaan pengabdian ini meliputi:

\section{a. Persiapan}

Tahap persiapan pengabdian meliputi koordinasi dengan mitra yakni aparatur desa yang berada di Desa Tlk. Latak, Kecamatan Bengkalis, Kab. Bengkalis. Melakukan beberapa persiapan sebelum pengabdian diantaranya, menghubungi perangkat desa, Kepala Desa setempat tentang rencana kegiatan pengabdian. Selanjutnya dilakukan komunikasi berkaitan dengan kegiatan yang dimaksud, serta menetapkan hari dan tanggal kegiatan.

Persiapan lain yang tim juga lakukan adalah menyiapkan materi, tempat dan keperluan alat pelindung diri bagi para mitra. Selain itu tim juga menyiapkan 
alat pendukung lain berupa Laptop, dan Infocus guna mendukung kegiatan pengabdian yang dimaksud.

\section{b. Pelaksanaan}

Kegiatan pengabdian dilaksanakan dengan metode ceramah dan tanya jawab. Upaya mencari solusi atas permasalahan yang terjadi pada kelompok mitra, pengabdian ini dirancang sedemikian rupa meliputi transfer pengetahuan teoritis tentang virus, media penularan virus, upaya pencegahan dan hikmah yang bisa diambil. Selain penjelasan secara Sains, pengabdi juga memberikan penanganan virus dalam perspektif islam. Hal itu dimulai dari bagaimana cara islam memandang wabah, upaya pencegahan hingga tanya jawab hukum tentang shalat berjamaah di masjid saat pandemi, memandikan mayit yang terinfeksi virus dan lainnya. Penyuluhan dilakukan secara tatap muka dan memperhatikan protocol kesehatan. Tahapan pelaksanaan pada Pengabdian Masyarakat ini adalah sebagai berikut :

1. Sambutan dari masing-masing pengisi acara.

2. Penyampaian materi mengenai penularan dan bahaya virus Covid19.

3. Edukasi tentang menjaga kebersihan diri dalam perspektif islam.

4. Memberikan informasi tentang wabah dalam sejarh islam

5. Penyampaian materi tentang Bagaimana cara islam memberikan solusi atas permasalahan wabah.

6. Penyerahan cindera mata dan alat prokes berupa masker dan masker dan hand sanitizer kepada perangkat desa.

\section{c. Evaluasi}

Akhir acara tim melakukan tanya jawab terkait permasalahan yang dihadapi selama pandemi terjadi. Mulai dari permasalahan keagamaan, kesehatan dan isu tentang konspirasi global terkait pandemi covid-19.

\section{HASIL DAN PEMBAHASAN}

Pelaksanaan kegiatan pengabdian kepada masyarakat dilaksanakan pada tangga 12 Desember 2020 yang lalu. Kegiatan bertempat di aula kantor desa Tlk. Latak kec. Bengkalis yang dimulai pada pukul 09.00 wib dan berakhir pada pukul 12.00 wib. Kegiatan diikuti oleh perangkat desa dan masyarakat desa. Tim pengabdi sendiri berasal dari fakultas Syariah dan Hukum, Fakultas Ekonomi dan Ilmu Sosial dan Fakultas Dakwah dan Komunikasi di lingkup UIN Sultan Syarif Kasim Riau.

Kegiatan pengabdian dimulai dengan sambutan yang dilakukan oleh Kepala Desa Tlk.Latak dalam hal ini diwakili oleh sekretaris desa. Dalam sambutannya sekretaris desa menyampaikan terima kasihnya karena sudah melaksanakan kegiatan ini. sekretaris desa juga menyampaikan kegiatan ini merupakan pengabdian masyarakat pertama yang dilaksanakan oleh instansi perguruan tinggi. Dalam kesempatan yang sama sekretaris desa juga meminta sesi tanya jawab yang lebih dalam.

Kegiatan dilanjutkan dengan sambutan dari ketua tim yang kemudian diikuti dengan penyampaian materi dalam upaya sharing knowledge tentang kebersihan dalam islam dan upaya pencegahan penularan covid-19. Materi awal dimulai dengan penjelasan tentang awal kemunculan covid-19. Dilanjutkan dengan cara penularan serta bahaya covid-19. Selain itu dalam kesempatan yang 
sama juga disampaikan bagaimana penyebaran wabah pada masa kejayaan islam dan penanganannya. Dari penjelasan tersebut, mitra diharapkan mendapat gambaran bagaimana langkah antisipasi dan melokalisir wabah saat itu.

Materi berikutnya tentang kebersihan dan pencegahan penularan covid19. Dalam pemaparannya pemateri Bapak Achmad Ghozali yang juga sebagai tim gugus tugas penanggulangan covid-19 NU (Nahdlatul Ulama) Wilayah Riau menyampaikan kewajiban seorang muslim untuk senantiasa menjaga kebersihan diri dan lingkungan. Kebersihan selain mendatangkan kebaikan dan rahmat juga merupakan bagian dari keimanan, seperti yang disampaikan dalam hadis nabi yang dikutip dari buku karangan An-Nawawi, I. (2015) artinya: Bersuci (thaharah) itu merupakan setengah dari iman (HR. Muslim). belum lengkap iman seorang hamba jika seseorang itu masih abai terhadap kebersihan diri dan lingkungan.

Beberapa cara yang bisa dilakukan dalam upaya menghindari penularan penyakit adalah dengan melindungi diri dan orang lain. menjaga kesehatan diri dan orang lain diantaranya dapat dilakukan dengan menerapkan etika bersin/batuk. Dalam buku Riyadhus Shalihin karya An-Nawawi, I. (2015), Dari abu hurairah, dia berkata" ketika sedang bersin, Rasulullah menutup mulutnya dengan tangan atau bajunya sambil menekan suaranya serendah mungkin (HR. Abu Dawud dan At-tirmidzi). Hal ini tentu sangat relevan dengan kondisi yang kita alami saat ini. Langkah ini dinilai cukup efektif karena sudah diketahui bahwa penularan virus dapat terjadi karena virus dapat tertular lewat air liur dan droplet yang tersembur saat batuk dan bersin.

Selain menutup mulut ketika bersin, upaya menjaga hidup sehat juga bisa dilakukan dengan mencuci tangan. Pemateri menerangkan bahwa berwudhu bisa menjadi cara pencegahan. Hal itu dapat dilakukan dengan menjalankan sunnahsunnah wudhu. Mencuci tangan dapat mengurangi dan membunuh mikroorganisme, bakteri, dan dapat membunuh virus penyebab penyakit (Dahlan dan Umrah, 2013); (Chittleborough, Nicholson, Young, Bell, \& Campbell, 2013). Walaupun Belum ada penelitian yang membuktikan apakah cuci tangan dengan sabun sesuai standar WHO mempunyai efektivitas yang sama dengan seseorang yang rutin berwudhu. Namun, secara logika, ketika seseorang rutin berwudhu, tentu ini akan berpengaruh terhadap kebersihan tangan.

praktik lain yang biasa kita lakukan sebelum berwudhu adalah disunahkan untuk menghirup air ke dalam hidung. Dalil yang menguatkan hal tersebut di riwayat kan oleh Humran yang artinya: "dari Humran bahwa Utsman RA meminta air wudhu:"lalu berkumur-kumur dan menghirup air dengan hidung dan mengembuskannya keluar, kemudian Utsman berkata: "Saya melihat Rasulullah SAW berwudhu seperti wudhu-ku ini." (HR Bukhari, Muslim). Dalam dunia kesehatan, yang dicontohkan Nabi ini dikenal dengan nama nasal irigation yaitu membersih-kan hidung dari korotran yang menempel (detik.com). kita bisa bayangkan, jika kita berwudhu 5 kali pada setiap waktu melakukan sholat, tentu rongga hidung kita akan senantiasa bersih.

Pada kesempatan yang sama, pemateri juga mensosialisasikan fatwa Majelis ulama indonesia (MUI) No 14 tahun 2020 tentang penyelenggaraan ibadah dalam situasi terjadi wabah covid-19 (Mudassir, 2020). Hal ini perlu di sampaikan mengingat masih banyak warga yang belum tahu. Misalnya soal mengganti shalat jum'at dengan sholat zuhur di rumah. Di beberapa tempat masih ada beberapa jamaah yang menyuarakan aksi protes terkait fatwa ini dan bersikeras untuk tetap melakukan ibadah jum'at di masjid (Rajab, Nurdin, \& Mubarak, 2020). padahal kalau kita cermati langkah ini dilakukan dalam upaya pencegahan. Hal 
ini sejalan dengan perintah nabi dalam sebuah hadist yang artinya: "larilah kalian dari penyakit lepra sebagaimana kalian lari ketika melihat singa (HR. Bukhari dan Muslim)." Hadits ini mengingatkan kita agar tidak menganggap enteng akan sebuah penyakit menular atau wabah, diantaranya dengan tidak berkerumun dan menghindari kontak fisik.

Perilaku hidup bersih dan sehat merupakan upaya untuk menularkan pengalaman baik ke individu atau kelompok masyarakat yang lebih luas. Beberapa upaya yang dapat dilakukan adalah dengan membagikan/memberikan materi edukasi guna menambah serta meningkatkan sikap dan perilaku hidup yang bersih dan sehat (Fatmawati, Ariyanto, \& Nurfitriani, 2019). Upaya itu dapat dilakukan dengan memberikan penyuluhan dan pendidikan kesehatan. Hal ini sejalan dengan Beberapa hasil penelitian yang dilakukan oleh (Syamsuar, Alam, \& Sari, 2018; Isnainy, Zainaro, Novikasari, Aryanti, \& Furqoni, 2020; Sukri, Syuryadi, \& Ernalia, 2020; Alsukri et al, 2021) dimana penyuluhan terbukti dapat meningkatkan pengetahuan mitra.

Pengabdian yang diikuti oleh aparatur desa dan warga masyarakat ini tampak begitu antusias. Pelaksanaan kegiatan sendiri dapat terlihat dari beberapa foto berikut:
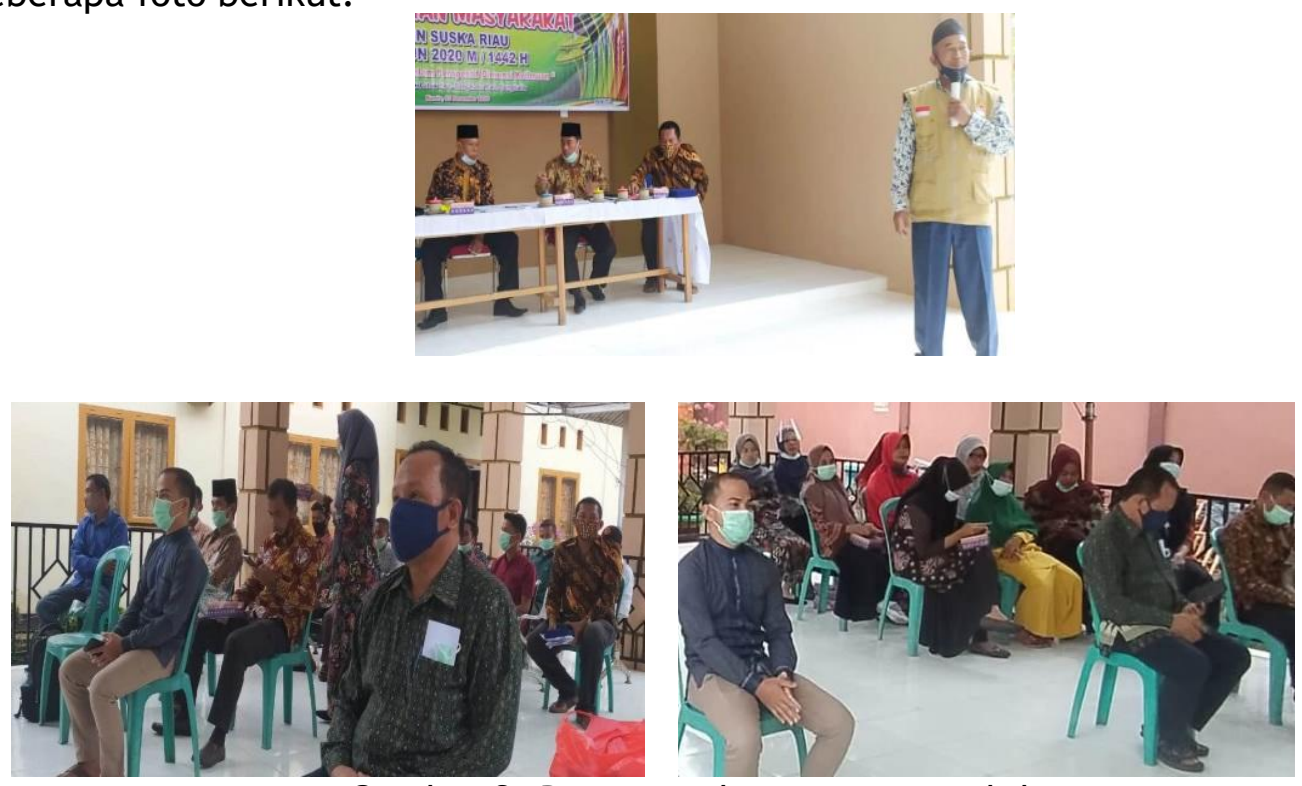

Gambar 2. Pemateri dan mitra pengabdian

Selain penyampaian materi, tim juga memberi ruang berinteraksi dengan memberikan kesempatan untuk bertanya seputar covid19 kepada mitra. Pertanyaan yang terekam dari peserta pada sesi tanya jawab seperti: Apakah wabah virus ini merupakan ujian atau hukuman dari Allah. Bagaimana hukum sholat di masjid dengan menjaga jarak antar makmum. Apakah virus ini merupakan konsfirasi global. Bagaimana cara memandikan mayit yang terinfeksi virus dan lainnya.

Pengabdian ditutup dengan penyerahan cindera mata, alat pelindung diri berupa, masker dan hand sanitizer. Setelah itu dilanjutkan dengan sesi foto bersama. 

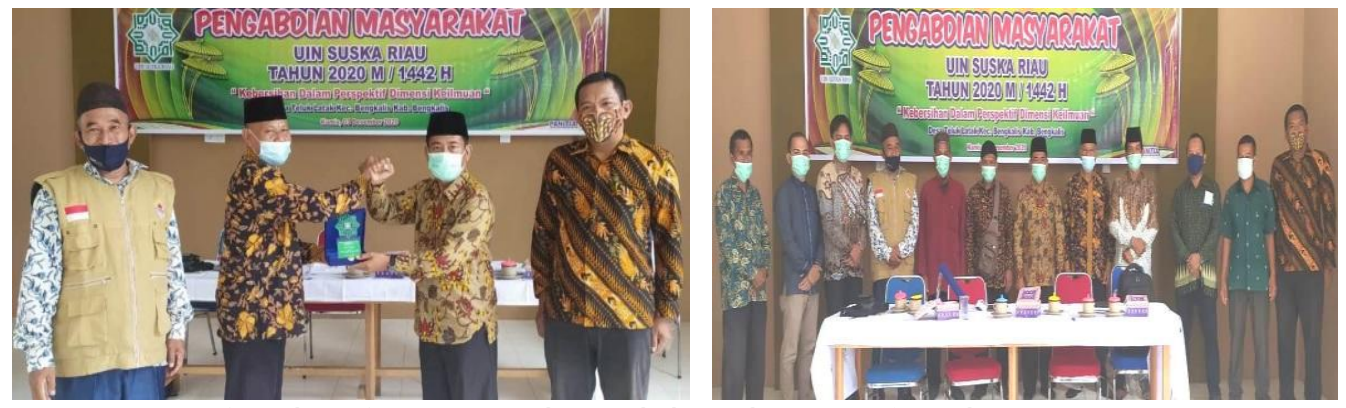

Gambar 3. Penyerahan plakat dan sesi foto bersama

\section{KESIMPULAN}

Pandemi covid19 mengajarkan kepada kita untuk menjaga diri dari perilaku hidup bersih dan sehat. Menajamin setiap makanan dan minuman yang kita konsumsi itu halal lagi baik. Senantiasa mengolah/memasak makanan dengan sempurna, menjaga kebersihan lahiriah, memperhatikan kebersihan diri dan lingkungan. Beberapa dari upaya menjaga kebersihan diri tersebut diantaranya dapat dipraktekkan pada saat kita berwudhu.

Selain merupakan musibah, seorang muslim harus bisa mengambil pelajaran dari apa yang terjadi sekarang. Inilah momentum kita untuk beradaptasi dengan cara hidup baru. Perubahan memang memberatkan dan seringkali membuat kita tidak nyaman namun apapun itu harus tetap dikerjakan dengan sikap sabar, terus belajar, berpikir positif dan beradaptasi dengan perubahan.

\section{UCAPAN TERIMA KASIH}

Pada akhirnya kami menyampaikan ucapan terima kasih kepada pihak Desa Tlk. Latak yang telah menerima, memberikan dukungan serta sambutan begitu hangat kepada tim pengabdi. Kemudian kepada Masyarakat Desa Tlk. Latak yang sudah meluangkan waktunya untuk dapat hadir dalam kegiatan ini sehingga pengabdian ini terlaksana dengan baik. Ucapan terima kasih juga kepada Bapak Dekan Fakultas Ekonomi dan Ilmu Sosial UIN Sultan Syarif Kasim Riau yang sudah memberikan kesempatan kepada kami untuk melaksanakan pengabdian ini.

\section{DAFTAR PUSTAKA}

Alsukri, S., Syuryadi, N., \& Ernalia, Y. (2020). PENINGKATAN PENGETAHUAN GIZI SEIMBANG DAN MITOS SEPUTAR GIZI PADA KELUARGA PRA-SEJAHTERA DI KELURAHAN DELIMA PEKANBARU. Martabe: Jurnal Pengabdian Kepada Masyarakat, 3(1), 108-115.

Al Sukri, S., Zulfahmi, Z., Ridha, I., Ilosa, A., Zulhaida, Z., Hayani, N., ... \& Wahyudi, H. (2021). EDUKASI POLA HIDUP BERSIH DAN SEHAT SERTA PENERAPAN ADAPTASI KEBIASAAN BARU PASCA PANDEMI COVID19. Martabe: Jurnal Pengabdian Kepada Masyarakat, 4(1), 274-281.

An-Nawawi, I. (2015). Riyadhus Shalihin. Pustaka Al-Kautsar.

Chittleborough, C. R., Nicholson, A. L., Young, E., Bell, S., \& Campbell, R. 
(2013). Implementation of an educational intervention to improve hand washing in primary schools: Process evaluation within a randomised controlled trial. BMC Public Health. https://doi.org/10.1186/1471-2458-13757

Dahlan, A. K., \& Umrah. (2013). Ajaran Ketrampilan Dasar Praktik Kebidanan. Malang: Inti Media

Depag. 1995. Al-qur'an dan terjemahannya. Jakarta: Depag R1.

Fatmawati, T. Y., Ariyanto, A., \& Nurfitriani, N. (2019). PKM PENINGKATAN PERILAKU HIDUP SEHAT PADA LANJUT USIA DI PANTI SOSIAL TRESNA WERDHA KOTA JAMBI. J-Dinamika. https://doi.org/10.25047/j-dinamika.v4i1.1055

Fehr, Anthony R and Perlman, \& Stanley. (2015). Coronaviruses: An Overview of Their Replication and Pathogenesis. In Coronaviruses: Methods and Protocols.

I.I., B., A., W., A., T.-B., C., H., M.U.G., K., \& K., K. (2020). Pneumonia of unknown aetiology in Wuhan, China: potential for international spread via commercial air travel. Journal of Travel Medicine.

Isnainy, U. C. A. S., Zainaro, M. A., Novikasari, L., Aryanti, L., \& Furqoni, P. D. (2020). Pendidikan Kesehatan Tentang Perilaku Hidup Bersih Dan Sehat (PHBS) Di SMA Negeri 13 Bandar Lampung. Jurnal Kreativitas Pengabdian Kepada Masyarakat (PKM).

Lu, H., Stratton, C. W. , \& Tang, Y. W. (2020). Outbreak of pneumonia of unknown etiology in Wuhan, China: The mystery and the miracle. Journal of Medical Virology. https://doi.org/10.1002/jmv.25678

Mudassir, R. (2020). Fatwa Lengkap MUI Terkait Pelaksanaan Ibadah saat Wabah Virus Corona Covid-19. Https://Kabar24.Bisnis.Com/.

Mustinda, lusiana. (2020). Manfaat wudhu: cegah bakteri hingga cerahkan wajah. https://news.detik.com/berita/d-4926741/manfaat-wudhu-cegah-bakterihingga-cerahkan-wajah (diakses tanggal 22 Februari 2020).

Rajab, A. J., Nurdin, M. S., \& Mubarak, H. (2020). Tinjauan Hukum Islam Pada Edaran Pemerintah Dan MUI Dalam Menyikapi Wabah Covid-19. BUSTANUL FUQAHA: Jurnal Bidang Hukum Islam.

Rifa'i, I., Irwansyah, F. S., Sholihah, M., \& Yuliawati, A. (2020). Dampak dan Pencegahan Wabah Covid-19: Perspektif Sains dan Islam. Jurnal Pendidikan.

Yuliana. (2020). Corona virus diseases (Covid -19); Sebuah tinjauan literatur. Wellness and Healthy Magazine.

Zheng, Y. Y., Ma, Y. T., Zhang, J. Y., \& Xie, X. (2020). COVID-19 and the cardiovascular system. Nature Reviews Cardiology. https://doi.org/10.1038/s41569-020-0360-5 